\title{
Value Added Tax and Economic Growth: An Empirical Study of China Perspective
}

\author{
Zeraibi Ayoub ${ }^{1^{*}}$, Subhadeep Mukherjee ${ }^{2}$ \\ ${ }^{*}$ Corresponding author
}

\begin{abstract}
This study investigates the role of Value-Added Tax (VAT) on the economic growth in China. The data used for the study is a time series of the period from 1985-2016. These researches use the gross domestic product (GDP) as a dependent variable. For the independent variables, this research using the total population, employed persons, consumer price index, and value-added tax. The current findings add to a growing body of literature on identifying the properties of VAT in China and identifying the tax system reform from 1993 to 2012 and the mechanism of transfer application of the business tax in the services sector to Value-Added Tax. The test result indicated to have a positive relationship between the GDP and independent variables value-added tax in both in the long and short run.
\end{abstract}

Keywords: value-added tax, economic growth, tax system

\begin{abstract}
Abstrak
Penelitian ini bertujuan menyelidiki peran pajak pertambahan nilai (PPN) terhadap pertumbuhan ekonomi di Cina. Datayang digunakan untukpenelitian ini adalah deret waktu selama periode 1985-2016. Variabel dependen yang dipergunakan ialah produk domestik bruot. Sedangkan variabel independennya ialah jumlah penduduk, orang yang dipekerjakan, indeks harga konsumen, pajak pertambahan nilai. Temuan saat ini menambah literatur yang berkembang tentang mengidentifikasi sifat-sifat PPN di Cina dan mengidentifikasi reformasi sistem perpajakan dari tahun 1993 hingga 2012 dan mekanisme aplikasi transfer pajak bisnis di sektor jasa ke Pajak Pertambahan Nilai. Hasil penelitian menunjukkan terdapat pengaruh positif dan signifikan antara variabel dependen (PDB) dan variabel independen (Re, PPN) baik dalam jangka panjang maupun jangka pendek.
\end{abstract}

Kata Kunci: pajak pertambahan nilai, pertumbuhan ekonomi, sistem perpajakan

JEL Code: F43, H21

How to Cite:

Ayoub, Z., \& Mukherjee, S. (2019). Value Added Tax and Economic Growth: An Empirical Study of China Perspective. Signifikan: Jurnal Ilmu Ekonomi, Vol. 8(2), 235-242. doi: http://dx.doi.org/10.15408/sjie.v8i2.10155. 


\section{Introduction}

Taxes have played a role in curbing the introduction of a new form of taxation. An increase in the tax rate and the increase in the income of the Government will put the sluggish risk of consumption to economic growth. It is a shortage of resources and not inadequate incentives, which limits the pace of economic development. Tax revenue is essential to accelerate the economic development (Basirat et al., 2014; Egbunike et al., 2018; Harelimana, 2018)

There is a temporary impact on the tax policy exogenous model growth is an endogenous growth model that affect permanent economic growth. There are some studies had investigated the relationship between taxation and economic growth such as Judd (1985), Stoilova (2017), Gashi et al., (2018), Iswahyudi (2018), and Milasi \& Waldmann (2018). There are five channel to measure the effect of tax on the growth of the economy: (1) Investment rates can be suppressed through taxes like corporate or personal income and capital gains tax; (2) A favorable leisure to the choice of distorting labor-leisure that can slow the growth of tax workforce; (3) Tax policy can affect productivity growth through its discouraging research and development costs; (4) Taxes may lead to the flow of resources to other sectors that may degrade productivity; (5) High taxes on labor supply can distort the efficient use of human capital by discouraging employers with high tax burdens.

The value-added tax (VAT) is a general term for all the provision to government rights, an obligation that arises the collection and administration of value-added taxes. Almost 130 countries had applied the value-added tax in the world (Keen \& Lockwood, 2010). In China, the regulation about value-added tax as promulgated by the state council on December 13, 1993 (hereafter the interim regulation on VAT). The VAT is a type of turnover that levy against the entities and natural persons that sell goods or provide labor services, such as processing, repair and again the importer over the value of the import goods. In order to the goal of tax reform in 2012, it was a gradual change in the business tax (BT) to the value-added tax (VAT). At which the initial stage and in the first stage, employ the VAT on the new sector (services sector). It was applied gradually to all over China, and the final applicant was utterly successful by May 1, 2016. The business tax (BT) was abandoned and started employing the VAT system in the service sectors.

Local investors will start investing overseas as the opportunity increases and the structure of the taxation problem for economic growth economic theory provides explanations for economic growth, and the reverse relationship of taxes raise or lower the cost back to the tax activity. People want to engage in activities that minimize their taxes, and some countries will increase, and some countries will not change their policy on taxation. Every type of tax distorts economic growth (Engen, 1996). Moreover, however, the economic downturn countries that appeared to be the most competitive in terms of taxation, which worsened the situation, found themselves in adverse circumstances when the Government's commitment to voters and the public could not be so quickly relieved.

This situation in the global economy has tried to budget and sustain government finances, as well as the short myopia of most governments in the country. The Chinese Government has set a series of value-added tax (VAT) reforms over the last few years to align the (VAT) system with internationally accepted principles in order to adapt much to the economic development 
of China and the world. The country's governance system and management abilities have been launched, aiming to modernize (Nasiru et al., 2016). Their study mentions that value-added tax has a positive direction signification between the VAT and economic growth and in concluding remarks. They also mention some recommendation that highlights the importance of the vat revenue and also its importance for economic growth.

Hassan (2015), and Inimino et al. (2018) states the positive impact of VAT on economic growth. Kalaš \& Milenkovič (2017) found a strong relationship between value-added tax and gross domestic product. Miki (2011) identified in the first trend of consumption and the economic growth display when the VAT rate change. Next, the second trend is having a pragmatical relationship between the VAT rate and the economic growth and aggregate consumption. Ahmad et al. (2013) conclude that direct taxes should be increased (rather than indirect taxes) to support economic prosperity.

Therefore, this paper meant to narrow the literature gap between the discussions of the contribution of one of most crucial public finance factor value-added tax contribution one china economic growth in the period of study between 1985 and 2018, and the relationship between the value government revenue and economic growth depending on an econometric model analysis and estimations to get the perfect evidence to answer to this critical debate discussed in study period results contrast to previous studies. This paper utilizes a heap of time series econometric methods to attain in-depth analysis.

Otherwise, this paper will discuss the effects of the value-added taxes on the economic growth in the period of study and the essential challenges to economic growth performance and one of public finance in China. Moreover, we will discuss how the descriptive and empirical study was; how economists and researchers find the relationship between the variables of the study.

We adopt an alternative econometric framework, namely the Auto-regressive Distributed Lag (ARDL) model. This framework is most appropriate since it allows potential both in the long run and short run asymmetries in the VAT different and GDP relations. So how did VAT affect China economics in general and China's economy? How can the value-added tax impact the economic growth in China? Many questions make economists face a significant challenge to say whether the China tax system effect can get with its economy or not. Through this study, we will try to make the closest view of how, when, and what would austerity measures do. This study is to evaluate the importance and performance of value-added tax in China in the period 1985-2016. Besides that, this research also examines the contribution of VAT on economic growth in the case of China.

\section{Method}

The data we using in this study is annually time series data in the period of 1985-2016. This study, using variables such as total population, employed persons, consumer price index, value-added tax, and GDP growth. This study is using the data from the World Bank and the National office of statistics. This research is to develop a new technique to disclose the relationship between the variables and avoided the problems by Auto-regressive Distributed Lag (ARDL). The model of this research as follows: 


$$
\begin{aligned}
& \Delta(G D P)=\pi r^{2}=\beta_{0}+\beta_{1}(G D P)+\beta_{2}(V A T)+\beta_{3}(R e)+e \\
& \Delta \operatorname{Lin}(G D P)=\beta_{0}+\beta_{1} \operatorname{Lin}(G D P)+\beta_{2} \operatorname{Lin}(V A T)+\beta_{3} \operatorname{Lin}(R e)+e
\end{aligned}
$$

Where: GDP is Gross domestic's production (100 million Yuan); VAT is value added tax (100 million Yuan); Re is China national revenue; and e is stochastic error term.

To find the relationship between variables we follow the Auto-regressive Distributed Lag (ARDL) equation:

$$
\begin{aligned}
\Delta \operatorname{Lin}(G D P)= & \beta_{0}+\sum_{i=1}^{n} n i \Delta \operatorname{Lin}(G D P)_{t-1}+\sum_{i=1}^{n} v i \Delta \operatorname{Lin}(V A T)_{t-1}+ \\
& i \sum_{i=1}^{n} \zeta i \Delta \operatorname{Lin}(R e)_{t-1}+\beta_{1} \operatorname{Lin}(G D P)_{t-q}+\beta_{2} \operatorname{Lin}(V A T)_{t-1}+ \\
& \beta_{3} \operatorname{Lin}(R e)_{t-1}+\omega_{t}
\end{aligned}
$$

\section{Result and Discussion}

Figure 1 shows that the Chinese national product during the period 1985-1995 he was in a state of increasing slow. After the period between 1995-2006, the Chinese economy rapidly grows due to economic reforms in the Chinese economy and similar to the slow pace during the years (Figure 1). Then, the Chinese economy accelerates during the period 2006-2018.

Figure 1. Gross Domestic Product in China

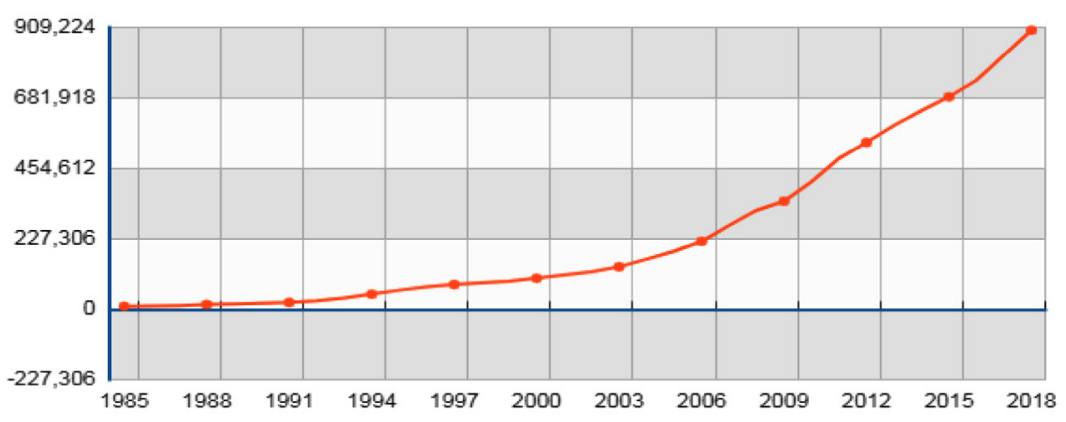

Figure 2 shows that the government revenue from value-added taxes during the year 1985-1995 was a little bit more than zero. However, during the period 1994-2000, the tax collection rose but increased, and the volume of returns increased. After 2000 the volume of high-volume added returns increased and accelerating between 2009 and 2018.

Figure 2. Domestic Value-added Tax

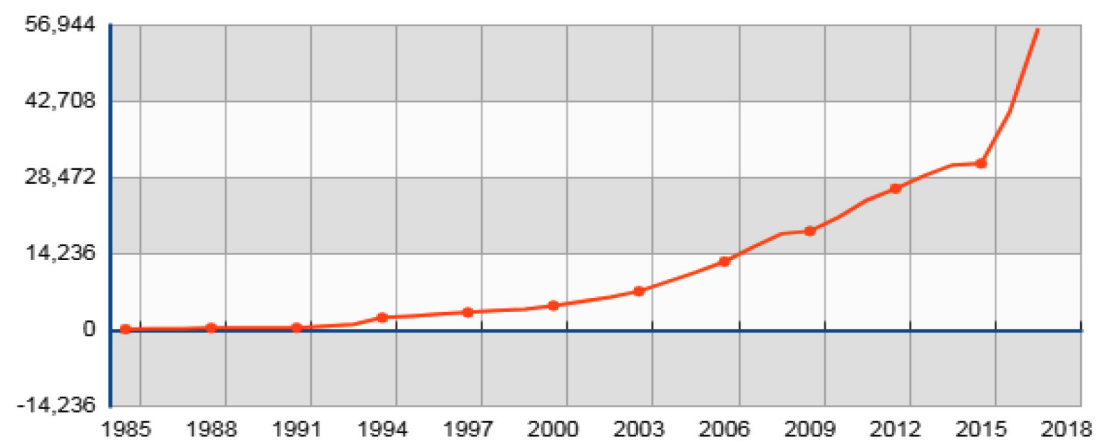


Unit root test, As for the empirical investigation, we are using time series data, for the analysis study, the essential step is the stationary test step, and in the stationary test have different econometric and statistics technique. In our case we chose the unit root test depending on the technique Phillips Peron (PP) (1988); also Dickey-Fuller (ADF) is between the critical test to test the stationary of the data. The objective of this step is to figure out a stationary and stable result. Table 1 shows the result of a stationary test by using the ADF test.

Table 1. The Result of ADF unit Root test

\begin{tabular}{ccccc}
\hline Variables & \multicolumn{2}{c}{ Level } & \multicolumn{2}{c}{$1^{\text {st }}$ Difference } \\
& t-value & Note & t-value & Note \\
\hline GDP & $2.405716^{*}$ & Stationary & -2.803135 & Stationary \\
Re & -1.111011 & Non-stationary & -5.126890 & Stationary \\
VAT & $4.801675^{*}$ & Stationary & 3.013277 & Stationary \\
\hline
\end{tabular}

According to the t-value test, we can accept or reject the null hypothesis of the stationary and non-stationary. The results of stationary indicate and show that the model does not have a problem (See Table 1). The bonds test is using in this research to investigate a simple integration between the variables in the model. Table 2 shows that the calculated F statistics equals 58.828 higher than the attribute value $5 \%$ indication level. This result means the nonexistent hypothesis does not exist, and there is no shared integrity and resolution for a shared integration between the form variables.

Table 2. Auto-regressive Distributed Lag (ARDL) Bound test

\begin{tabular}{ccc}
\hline \multicolumn{3}{c}{ F statistics $=5.525, \mathrm{~K}=\mathbf{2}$} \\
\hline Significance & Lower Bound Value I(0) & The Upper bound value I(1) \\
\hline $10 \%$ & 2.63 & 3.35 \\
$5 \%$ & 3.1 & 4.87 \\
$2.5 \%$ & 3.55 & 4.38 \\
$1 \%$ & 4.14 & 5 \\
\hline
\end{tabular}

Source: Data processing.

Table 3 shows the result shows that it has a positive relationship between the VAT and GDP short-term. Table 3 also shows The Re significance result; it means that there is a short-run relationship between the GDP and China national revenue. The result in Table 3 also indicates the constant $\mathrm{P}$-value $=0.000$ that means to have a positive direct relationship between the dependent variable (GDP) and the independent variables the (Re, VAT) in the long run. 
Table 3. The Long Run Relationship

\begin{tabular}{cccc}
\hline Variable & Coefficient & T-value & p-value \\
\hline $\mathrm{R}_{\mathrm{e}}$ & 2.7350 & 11.13594 & 0.0011 \\
$\mathrm{~V}_{\text {AT }}$ & 7.7469 & 5.4747 & 0.0002 \\
$\mathrm{C}$ & 28715.78 & 17.03 & 0.0000 \\
\hline
\end{tabular}

Source: Data processing

According to the Table 4 result, ECM (-1) indicates a negative coefficient $[(-0.62) \leq$ $(-1.5)]$. The result indicates that the speed of the adjustment is $62 \%$ per period. The result from Table 4, the model converged back to equilibrium by percent since the coefficient of correction term is negative and significant. There is a long-run relation association between Vat components and economic performance in China; although tax policies may have a short-run effect on the people, in the long run, everything would come normal.

Table 4. ARDL Result of Error correction model in the long run

\begin{tabular}{cccc}
\hline Variable & Coefficient & T-value & P-value \\
\hline $\mathrm{D}(\mathrm{Re})$ & 2.8362 & 17.3124 & 0.000 \\
$\mathrm{D}\left(\mathrm{V}_{\mathrm{AT}}\right)$ & 3.1620 & 15.7854 & 0.000 \\
$\mathrm{ECM}(-1)$ & -0.6291 & -3.3901 & 0.0003 \\
\hline
\end{tabular}

Source: Data processing.

From the long run results in Table 4, VAT was positive and also significant in the short run. This result indicates that vat in a viable when it comes to economic decision making in the country. The China government must be able to generate enough revenue to meet up with the challenges of her expenditures regarding the provision of social amenities and the running cost of the Government. There are some studies had found the same result with this research (Hassan, 2015; Inimino et al., 2018). The result shows that positive relationship between the value-added tax and growth of the economy in some countries. Integrative tax offices should be strengthened to increase efficiency and effectiveness (Adegbie et al., 2016)

This research is different from Lee \& Gordon (2005), McNabb (2018), and Uchime \& Anichebe (2019) that found a negative relationship between incomes taxes and GDP growth. Hajdúchová et al. (2015) conclude that the share of VAT on total tax revenues, after the increase in the VAT rate did not increase. The positive effect of VAT on the level of economic growth seems to have imposed through channels other than the increase of saving and its effect on capital accumulation (Kolahi \& Noor, 2016). Macek (2014) suggest that the Government should lower corporate taxation and personal incomes tax to stimulate the economic growth in OECD countries. The loss of income tax revenues will compensate for the growth of indirect tax revenues. Alavuotunki et al. (2019) state that income-based inequality has increased due to VAT adoption. Lin \& Jia (2019) recommends that tax cuts will have a favorable implication for the economy if a country has reached the top of the Laffer curve. 
We had figure out the role of VAT in the economy in the short and long term; This study provides an alternative look at China's economic growth sources and a study supporting empirical evidence. The result demonstrates the role of VAT in the Chinese economy in studies related to the subject of value-added tax and its role in economic growth.

\section{Conclusion}

The VAT plays a vital role in the economic growth in the case of China. The current findings add to a growing body of literature on identifying the properties of VAT in China and identifying the tax system reform in 1993 and 2012. This study has confirmed the findings from previous studies that show a positive relationship between VAT and economy growth in the long run. Although the present study based on a limited sample of participants, and the findings suggested that the ARDL model test the signification relationship between the variables in the long and short run.

This study helped the researcher to understand and evaluate the importance and performance of value-added tax in China in the period 1985-2016 with forecasting on the contribution of vat on the economic growth in the case of China. Future studies are also advised to use other variables that have not listed in the model, such volume of exports and volume of foreign investment flows in China during variables as a whole and use the NARDL for more detailed calculations.

\section{References}

Adegbie, F. F., Olajumoke, J., Danjuma, K. J. (2016). Assessment of Value Added Tax on the Growth and Development of Nigeria Economy: Imperative for Reform. Accounting and Finance Research, 5(4), 163-178. https://doi.org/10.5430/afr.v5n4p163.

Ahmad, N., \& Ahmad, A., \& Yasmeen, K. (2013). The Impact of Tax on Economic Growth of Pakistan: An ARDL Approach. Journal of Basic and Applied Scientific Research, 3(11), 392-398.

Alavuotunki, K., Haapanen, M., \& Pirttiä. (2019). The Effects of the Value-Added Tax on Revenue and Inequality. The Journal of Development Studies, 55(4), 490-508. https:// doi.org/10.1080/00220388.2017.1400015.

Basirat, M., Aboodi, F., \&, Ahangari, A. (2015). Analyzing the effect of economic variables on total tax revenues in Iran. Asian Economic and Financial Review, 4(6), 755-767.

Egbunike, F. C., Emudainohwo, O. B., \& Gunardi, A. (2018). Tax Revenue and Economic Growth: A Study of Nigeria and Ghana. Signifikan: Jurnal Ilmu Ekonomi, 7(2), 213220. https://doi.org/sjie.v7i2.7341.

Engen, E. M., \& Skinner, J. (1992). Fiscal Policy and Economic Growth. NBER Working Paper No. w4223. National Bureau of Economic Research.

Gashi, B., Assllani, G., \& Boqolli, L. (2018). The Effect of Tax Structure on Economic Growth, International Journal of Economics and Business Administration, 6(2), 56-67.

Hajdúchová, I., Sedliačiková, M., \& Viszlai, I. (2015). Value-added Tax Impact on the State 
Budget Expenditures and Incomes. Procedia Economics and Finance, 34, 676-681. https://doi.org/10.1016/S2212-5671(15)01685-8.

Hassan, B. (2015). The Role of Value Added Tax in the Economic Growth of Pakistan. Journal of Economics and Sustainable Development, 6(13), 174-183.

Inimino, E. E., Otubu, O. P., \& Akpan, J. E. (2018). Value Added Tax and Economic Growth in Nigeria. International Journal of Research and Innovation in Social Sciences, 2(10), 211-219.

Iswahyudi, H. (2018). Do Tax Structures Affect Indonesia's Economic Growth? Journal of Indonesian Economy and Business, 33(3), 216-242. https://doi.org/10.22146/jieb.29033.

Harelimana, J. B. (2018). The Role of Taxation on a Resilient Economy and Development of Rwanda. Review Article Journal, 2(1), 28-39.

Judd, K. L. (1985). Redistributive Taxation in a Simple Perfect Foresight Model. Journal of Public Economics, 28(1), 59-83. https://doi.org/10.1016/0047-2727(85)90020-9.

Kalaš, B., \& Milenkovič, N. (2017). The Role of Value Added Tax in the Economy of Serbia. Ekonomika, 63(2), 69-78. https://doi.org/10.5937/ekonomika.1702069K.

Keen, M., \& Lockwood, B. (2010). The Value Added Tax: Its Causes and Consequences. Journal of Development Economics, 92, 138-151. https://doi.org/10.1016/j.jdeveco.2009. 01.012

Kolahi, S. H. G., \& Noor. Z. B. M. (2016). The Effect of Value Added Tax on Economic Growth and Its Sources in Developing Countries. International Journal of Economics and Finance, 8(1),1-14. https://doi.org/10.5539/ijef.v8n1p217.

Lee, Y., \& Gordon, R. H. (2005. Tax Structure and Economic Growth. Journal of Public Economics, 89(5-6), 1027-1043. https://doi.org/10.1016/j.jpubeco.2004.07.002.

Lin, B., \& Jia, Z. (2019). Tax Rate, Government Revenue and Economic Performance: a Perspective of Laffer Curve. China Economic Review, 56. https://doi.org/10.1016/ j.chieco.2019.101307.

Macek, R. (2014). The Impact of Taxation on Economic Growth: Case Study of OECD Countries. Review of Economic Perspectives, 14(4), 309-328. https://doi.org/10.1515/ revecp-2015-0002.

McNabb, K. (2018). Tax Structures and Ecoomic Growth: New Evidence from the Government Revenue Dataset. Journal of Internatonal Development, 30(2), 173-205. https://doi.org/10.1002/jid.3345.

Miki, B. (2011). The Effect of the VAT Rate Change on Aggregate Consumption and Economic Growth. Working Paper Series No. 297.

Milasi, S., \& Waldmann, R. J. (2018). Top Marginal Taxation and Economic Growth. Applied Economics, 50(19), 2156-2170. https://doi.org/10.1080/00036846.2017. 1392001.

Nasiru, M. G., Haruna, M. A., \& Abdullahi, M. A. (2016). Evaluating the Impact of Value Added Tax on the Economic Growth of Nigeria. Journal of Accounting and Taxation, 8(6), 59-65.

Stoilova, D. (2017). Tax Structure and Economic Growth: Evidence from the European Union. Contaduria y Administracion, 62(3), 1041-1057. https://doi.org/10.1016/j.cya. 2017.04.006.

Uchime, H. N., \& Anicheve, A. S. (2019). Effect of Taxation on Domestic Investment in Nigeria. International Journal of Economics, Business, and Management Studies, 6(1), 96-104. 